\title{
A Rare Cause of Hypoxemia: Hereditary Methemoglobinemia
}

\section{Nadir bir Hipoksemi Sebebi; Herediter Methemoglobinemi}

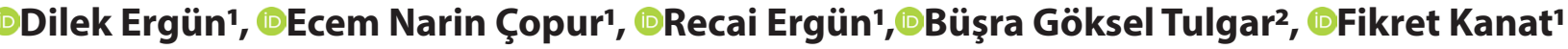 \\ 'Selcuk University School of Medicine Department of Chest, Konya, Turkey \\ ${ }^{2}$ Selcuk University School of Medicine Department of Medical Genetics, Konya, Turkey
}

\begin{abstract}
Hereditary methemoglobinemia is one of the rare causes of hypoxemia. Mutations in the CYB5R3 gene cause autosomal recessive hereditary methemoglobinemia. Mostly, symptoms such as shortness of breath, bruise and and fatique occur. It may not display any symptoms until adult ages. Our case was at the age of 18 and had sometimes recurring bruise in hands and lips, shortness of breath, palpitations and oxygen saturation $\left(\mathrm{SaO}_{2}\right)$ was $85 \%$. Methemoglobin (Methb) level was $\% 20(\mathrm{~N} ; 0-1.5)$ No cardiac or pulmonary cause could be detected, which could account for dyspnea and cyanosis, and due to low saturation and high Methb. levels, metheglobinemia was considered and high dose IV ascorbic acid was administered. In follow up period, saturation increased and Methb. level gradually decreased and with genetic tests, homozygous missense c.136C > T (p.R46W) mutation was detected with CYB5R3 gene sequence analysis. Patient was diagnosed with autosomal recessive hereditary methemoglobinemia type 1. This case is presented in order to emphasize that hereditary methemoglobinemia should be kept in mind when shortness of breath, hypoxia and cyanosis, occur together and can not be attributed to pulmonary and cardiovascular causes.
\end{abstract}

Keywords: Hereditary methemoglobinemia, CYB5R3 gene mutation, hypoxemia, dyspnea, cyanosis

\section{INTRODUCTION}

Hereditary Methemoglobinemia, is one of the rare causes of hypoxemia. Methemoglobin (MetHb), is the non functional form of hemoglobin produced by transformation of ferrous $\left(\mathrm{Fe}^{+2}\right)$ hemoglobin iron to ferric form $\left(\mathrm{Fe}^{+3}\right)$ by oxidation. Methemoglobin can not transport oxygen and hence tissue hyoxia and cyanosis arises. In normal metabolism, due to erithrocyte enzyme systems (NADH-cytochrome b5 reductase and NADPH Methb reductase ), MetHb level is kept

\section{Öz}

Herediter Methemoglobinemi hpokseminin nadir sebeplerinden biridir. CYB5R3 geninde oluşan mutasyonlar otozomal resesif herediter methemoglobinemiye neden olur. Çoğunlukla nefes darlığı, morarma, halsizlik gibi semptomlar görülebilir. Bazen erişkin yaşa kadar semptom vermeyebilir. Onsekiz yaşında ellerinde ve dudaklarında zaman zaman tekrarlayan morluk, nefes darlığı, çarpıntısı olan olgumuzun, pulseoksimetre ile ölçülen oksijen satürasyonu $\left(\mathrm{SpO}_{2}\right) \% 85$ saptandı. Methemoglobin (Methb) düzeyi \%20 (N;0-1,5) idi. Dispne ve siyanozu açıklayacak kardiyak ve pulmoner neden saptanmayan olguda satürasyonu düşüklüğü ve methb yüksekliği nedeniyle methemoglobinemi düşünülerek, yüksek doz ıntravenöz askorbik asit verildi. Satürasyonu yükselen ve methb düzeyi tedricen düşen hastanın takiplerinde genetik testler sonucunda CYB5R3 geni sekans analizi ile homozigot missense c.136C > T (p.R46W) mutasyonu saptandı. Hasta otozomal resesif herediter methemoglobinemi tip 1 olarak kabul edildi. Pulmoner ve kardiyovasküler nedenlerle açıklanamayan nefes darlığı, hipoksi, siyanoz birlikteliğinde nadir görülen herediter methemoglobineminin akla gelmesi gerektiğini vurgulamak için bu vakamızı sunuyoruz.

Anahtar kelimeler: Herediter methemoglobinemi, CYB5R3 gen mutasyonu, hipoksemi, dispne,siyanoz under $1 \%$. Congenital deficiency or acquired impairment of these systems lead to Methemoglobinemia, which may be innate or acquired. ${ }^{[1]}$

Hereditary methemoglobinemia is a rarely occurring disease all over the world and its prevalence and incidence is unknown. Hereditary methemoglobinemias may not exhibit any symptoms until adult ages. ${ }^{[2]}$ The CYB5R3 gene, located in the chromosome 22 q13.2 region, is involved in 
the synthesis of the enzyme named Nicotinamide-adenine dinucleotide (NADH) -cytochrome b5 reductase. ${ }^{[3,4]}$ The CYB5R3 gene, which consists of nine exons, is $32 \mathrm{~kb}$ in size. ${ }^{[5]}$ There are two known isoforms of (NADH) -cytochrome b5 reductase enzyme, the membrane-bound form found in all somatic cells, and the soluble form found only in erythrocytes. Its membrane-bound form functions in the elongation and desaturation of fatty acids, cholesterol biosynthesis, and the metabolism of various molecules and drugs. The soluble form found in erythrocytes takes place in the electron transport system to reduce methemoglobin to functional hemoglobin. ${ }^{[6]}$ Mutations in the CYB5R3 gene cause autosomal recessive congenital methemoglobinemia. ${ }^{[7]}$ There are two different phenotypes of thedisease, type 1 and type 2, depending on the functional change caused by the mutation in gene function. CYB5R3 gene mutations that cause autosomal recessive congenital methemoglobinemia type 1 typically decrease enzyme activity or stability, and the only finding observed in the sick individual is cyanosis. ${ }^{[7]}$ Ferric iron $\left(\mathrm{Fe}^{3+}\right)$ cannot be converted effectively to ferrous iron $\left(\mathrm{Fe}^{2+}\right)$, which causes an increase in the erythrocyte's methemoglobin. Autosomal recessive congenital methemoglobinemia type 2 occurs if the mutation in the CYB5R3 gene leads to a complete loss of function in the enzyme, resulting in a more severe clinical picture..$^{[8-11]}$

This case is presented to emphasize that hereditary methemoglobinemia, which is one of the rare causes of hypoxemia, should be borne in mind in cases presenting with dyspnea, cyanosis and hypoxemia.

\section{CASE}

An 18 year old female patient presented with the symptoms of bruise in lips and hands and dyspnea. In history, it was learned that she had recurrent bruise in the past and underwent investigation a few times for this reason since childhood, but the cause could not be found. Patient did not receive any drug or anesthetic before admission for any reason. In physical examination, cyanosis was detected in finger tips and lips and respiratory system examination were normal. In cardiovascular system examination, tachycardia was observed (120/min). In ambient air, with pulse oximeter, oxygen saturation was found to be $\left(\mathrm{SpO}_{2}\right) \% 85$. Hematological and biochemical parameters were unremarkable. Lung graphy and respiratory function tests were normal.

In arterial blood gas, partial oxygen pressure $\left(\mathrm{PaO}_{2}\right)$ was 99 $\mathrm{mmHg}, \mathrm{SaO}_{2} \% 96$ and Methemoglobin (Methb) level \%20 $(\mathrm{N} ; 0-1.5)$. Saturation gap was \% $11(\mathrm{~N}<\% 5)$ In investigations carried out for pulmonary embolism, no pathology was found. Echocardiography results were also normal. No pulmonary or cardiological pathology was detected and peripheral blood smear and hemoglobin electrophoresis yielded normal results as well. Since there was no cause which could explain hypoxia and cyanosis and metHb level was high, methemoglobinemia was considered. Patient was administered high dose IV Vitamin
C ( $3 \times 500 \mathrm{mg})$. This dose was repeated a few times. Subsequent to treatment, cyanosis improved and level of methemoglobin gradually decreased. Pulse oxygen saturation increased to $93 \%$. As a result of the genetic examinations of the patient, homozygous missense c.136C> T (p.R46W) mutation was detected with CYB5R3 gene sequence analysis. The mutation was in the exon 2 region of the gene, resulting in there placement of the positively charged arginine amino acid at codon 46 with the non-polar neutral amino acid tryptophan. The detected variant was evaluated as pathogenic in analysis using public in silico prediction tools such as Mutation Taster and Varsome.

Patient was considered as autosomal recessive hereditary methemoglobinemia type 1 in view of recurrent cyanosis, absence of drug or anesthetic substance use, high Methb level and the presence of mutation in cytochrome b5 reductase (CYB5R3) gene (c.136C>p.R46W) and mild to moderate clinical picture. There is consanguinity in our patient's parents. In the segregation analysis, heterozygous mutations were detected in the same region in both parents of the patient. The absence of any findings related to the disease in the mother and father was found to be compatible with the heterozygous situation. There is no known individual with a history of similar disease in the patient's pedigree. According to the autosomal recessive inheritance pattern, the patient and her family were given genetic counseling, and the patient was informed about the $25 \%$ risk of affecting each sibling, 50\% risk of being an asymptomatic carrier, and $25 \%$ healthy.

\section{DISCUSSION}

Hereditary methemoglobinemia diagnosis is made with deficiency of cytochrome b5 reductase enzyme or presence of $\mathrm{M}$ hemoglobins. Cytochrome b5 reductase gene is located on chromosome 22. To date, 43 different cytochrome $B 5$ reductase gene mutations have been described. Cytochrome b5 reductase enzyme deficiency Type 1 is the most common one. ${ }^{[12]}$ In this patient group, solely enzyme deficiency is present in erythrocytes. Depending upon methemoglobin level, at times, fatigue and dyspnea and cyanosis occur. Blood MetHb level is under $1 \%$ in normal conditions. When MetHb level increases over $1.5 \mathrm{~g} / \mathrm{dl}$, cyanosis starts to appear and becomes marked when MetHb level reaches 10\%. Unless MetHb level rises over $\% 25-40$ or cardiopulmonary dysfunction is present, normal life can be expected in this group. However, in Type 2, enzyme deficiency is present in many tissues such as liver, fibroblast and brain in addition to erythrocytes. Neurological syndrome encompassing severe mental retardation, growth delay, opisthotonus and generalized symptoms is encountered. Clinical picture is quite severe. ${ }^{[13,14]}$

It has been demonstrated that many agents cause acquired methemoglobinemia. The most common causes are sulphonamides, local anesthetic drugs and nitrate containing vegetables. Acquired methemoglobinemia may have a more severe clinical course than hereditary one. ${ }^{[12]}$ While 
no symptoms and signs may be observed in mild cases, in severe cases,cyanosis,tachypnea, tachycardia, hypotension, confusion and even death may occur. ${ }^{[13]}$

In hereditary methemoglobinemia, diagnosis is made based on the appearance of cyanosis, which does not have a respiratory or cardiovascular background and does not respond to oxygen treatment. Recurrent cyanosis and presence of family history suggests hereditary methemoglobinemia, whilst methemoglobinemia produced by drug and chemical substances suggests acquired form. In spite of cyanosis, arterial blood oxygen pressure is within normal range. Oxygen saturation may be low. Definitive diagnosis is made with the measurement of blood level and demonstration of deficiency in cytochrome B5 reductase enzyme. Type 1 enzyme deficiency is in merely erythrocytes, while in type 2, it is in both erithrocytes and leukocytes. ${ }^{[15]} \mathrm{At}$ present, there is no cure for hereditary methemoglobinemia. These patients should avoid oxidizing drugs. For cosmetic defects, (blue skin), treatment with ascorbic acid (300-500 mg/ day), methylene blue (100-30 mg/day and riboflavin (60-120 $\mathrm{mg} /$ day) is recommended. ${ }^{[15]}$

In our patient, dsypnea, cyanosis and hypoxemia, which did not improve despite oxygen treatment, were present. In view of low saturation, high methemoglobin levels and the presence of mutation in cytochrome b5 reductase (CYB5R3) gene and the response to Vitamin $C$, hereditary methemoglobinemia type 1 enzyme deficiency was considered. Patient was recommended to avoid oxidizing drugs.

\section{CONCLUSION}

In the combination of dyspnea, hypoxia and cyanosis, which can not be explained by respiratory and cardiovascular causes, autosomal recessive hereditary methemoglobinemia type 1, which is a rare entity, should be kept in mind.

\section{ETHICAL CONSIDERATIONS}

Informed Consent: Written informed consent was obtained from all participants who participated in this study.

Status of Peer-review: Externally peer-reviewed.

Conflict of Interest Statement: The authors have no conflicts of interest to declare.

Financial Disclosure: The authors declared that this study has received no financial support.

Author Contributions: All of the authors declare that they have all participated in the design, execution, and analysis of the paper, and that they have approved the final version.

\section{REFERENCES}

1. Fermo $E$, Bianchi $P$, Vercellati $C$, et al. Recessive hereditary methemoglobinemia: two novel mutations in the NADH-cytochrome b5 reductase gene. Blood Cells Mol Dis 2008;41(1):50-5.
2. Mansouri A, Lurie AA. Concise review: methemoglobinemia. Am J Hematol 1993;42(1):7-12.

3. Fisher RA, Povey S, Bobrow M, Solomon E, Boyd Y, Carritt B. Assignment of the DIA1 locus to chromosome 22. Ann Hum Genet 1977;41(2):151-5.

4. Gupta V, Kulkarni A, Warang P, Devendra R, Chiddarwar A, Kedar P. Mutation update: Variants of the CYB5R3 gene in recessive congenital methemoglobinemia. Hum Mutat 2020;41(4):737-48.

5. Tomatsu S, Kobayashi Y, Fukumaki Y, Yubisui T, Orii T, Sakaki Y. The organization and the complete nucleotide sequence of the human NADH-cytochrome b5 reductase gene. Gene. 1989;80(2):353-61.

6. Katsube T, Sakamoto N, Kobayashi $\mathrm{Y}$, et al. Exonic point mutations in $\mathrm{NADH}$-cytochrome B5 reductase genes of homozygotes for hereditary methemoglobinemia, types I and III: putative mechanisms of tissuedependent enzyme deficiency. Am J Hum Genet 1991;48(4):799-808.

7. Rehman HU. Methemoglobinemia. West J Med. 2001;175(3):193-6.

8. Lorenzo FR 5th, Phillips JD, Nussenzveig R, et al. Molecular basis of two novel mutations found in type I methemoglobinemia. Blood Cells Mol Dis 2011;46(4):277-81.

9. Hudspeth MP, Joseph S, Holden KR. A novel mutation in type II methemoglobinemia. J Child Neurol 2010;25(1):91-3.

10. Warang PP, Kedar PS, Shanmukaiah C, Ghosh K, Colah RB. Clinical spectrum and molecular basis of recessive congenital methemoglobinemia in India. Clin Genet. 2015;87(1):62-7.

11. Arikoglu T, Yarali N, Kara A, et al. A novel L218P mutation in NADHcytochrome b5 reductase associated with type I recessive congenital methemoglobinemia. Pediatr Hematol Oncol 2009;26(5):381-5.

12. Jaffé ER. Enzymopenic hereditary methemoglobinemia: a clinical/ biochemical classification. Blood Cells. 1986;12(1):81-90.

13. Kaplan JC, Lostanlen D, Gacon G, Leroux A. La réduction enzymatique de la méthémoglobine [Enzymatic reduction of methemoglobin]. Expos Annu Biochim Med. 1980;34:81-94. French.

14. Takeshita M, Tamura M, Kugi M, Matsuki T, Yoneyama Y, Igarashi T. Decrease of palmitoyl-CoA elongation in platelets and leukocytes in the patient of hereditary methemoglobinemia associated with mental retardation. Biochem Biophys Res Commun. 1987;148(1):384-91.

15. Svecová $D$, Böhmer $D$. Vrodená a získaná methemoglobinémia a ich liecba [Congenital and acquired methemoglobinemia and its therapy]. Cas Lek Cesk. 1998;137(6):168-70. Slovak. 